\title{
THE RELATION OF DIETARY NITROGEN CONSUMPTION TO THE RATE OF URIC ACID SYNTHESIS IN NORMAL AND GOUTY MAN ${ }^{1}$
}

\author{
By EDWARD J. BIEN, T. F. YU, JEAN D. BENEDICT, ALEXANDER B. GUTMAN, \\ AND DEWITT STETTEN, JR. \\ (From the Division of Nutrition and Physiology, the Public Health Research Institute of the \\ City of New York, Inc., New York; Department of Medicine, The Mount Sinai \\ Hospital, New York)
}

(Submitted for publication January 15, 1953; accepted May 1, 1953)

In earlier studies the rate of incorporation of dietary glycine nitrogen into uric acid was measured in normal and gouty men $(1,2)$. The experimental procedure employed was to add a fixed quantity (100 mg. per $\mathrm{Kg}$. of body weight) of glycine- $\mathrm{N}^{15}$ to the diet and to determine both the quantity of urinary uric acid and its isotope content during the succeeding time intervals.

In view of the increase in urinary uric acid excretion which follows increased consumption of dietary protein, it has been deemed advisable, in some clinics, to restrict the protein intake in gout. It was considered of interest to explore the possible relationship between the level of protein in the diet and the rate of incorporation of dietary glycine nitrogen into uric acid in order to ascertain whether an increase in the rate of uric acid synthesis was indeed demonstrable when the consumption of dietary protein was enhanced.

\section{MATERIAL AND METHODS}

One normal (E. B.) and one gouty subject (D. R.) were selected for this study. Both have already been described (1), the gouty subject being known to excrete

1 This work was carried out with the support of a grantin-aid from the National Institute of Arthritis and Metabolic Diseases, National Institutes of Health. excessive quantities of uric acid in the urine and to incorporate glycine- $\mathrm{N}^{15}$ at an augmented rate when maintained on a low protein diet (1).

Two experiments were conducted on each subject, the first while on a relatively low purine diet (2), the second on the same diet fortified with skimmed milk powder (Lonalac) to increase the protein intake significantly (Table I) without material increase in fat, carbohydrate or total calories. A suitable interval, of 10 to 12 months, was allowed to elapse between experiments on each of these subjects in order to ensure absence of detectable isotopic enrichment after the initial feeding of $\mathrm{N}^{15}$-labeled glycine, as was demonstrated in each instance. The subjects were maintained on their respective diets at least one week before the dose of glycine- $\mathrm{N}^{15}$ was administered.

The same dosage of glycine- $\mathrm{N}^{25}$ was used in all experiments (100 mg. per $\mathrm{Kg}$. body weight). All of the synthetic and analytical methods employed were those previously described $(1,2)$.

\section{RESULTS}

Despite the fact that the isotopic glycine must have undergone somewhat greater dilution by nonisotopic glycine prior to absorption from the intestine when the diet was fortified with protein, the uric acid excreted in the early period by both of these subjects was richer in isotope when they were on a high protein regimen (Table I, Figure 1). This indication that incorporation of glycine

TABLE I

Per cent of dose of administered $N^{15}$ excreted as uric acid and as total nitrogen by a normal (E. B.) and a gouty (D. R.) subject over a nine day period on a relatively low and relatively high protein diet

\begin{tabular}{|c|c|c|c|c|c|c|}
\hline \multirow[b]{2}{*}{ Subject } & \multirow{2}{*}{$\begin{array}{c}\text { Protein } \\
\text { intake } \\
\text { g. }\end{array}$} & \multicolumn{2}{|c|}{ Daily excretion } & \multicolumn{2}{|c|}{ Per cent of $\mathrm{N}$ fed excreted as } & \multirow{2}{*}{$\begin{array}{l}\text { Per cent of } \\
\text { excreted N1 } \\
\text { in uric acid } \\
(100 B / A)\end{array}$} \\
\hline & & $\begin{array}{c}\text { Total } \mathbf{N} \\
\text { g. }\end{array}$ & $\begin{array}{c}\text { Uric acid N } \\
\text { mg. }\end{array}$ & $\begin{array}{c}\text { Total } N \\
(A)\end{array}$ & $\begin{array}{c}\text { Uric acid } N \\
\text { (B) }\end{array}$ & \\
\hline $\begin{array}{l}\text { E. B. (1) } \\
\text { E. B. (2) } \\
\text { D. R. (1) } \\
\text { D. R. (2) }\end{array}$ & $\begin{array}{r}48 \\
84 \\
68 \\
108\end{array}$ & $\begin{array}{r}7.6 \pm 0.5^{*} \\
13.4 \pm 0.8 \\
10.8 \pm 0.4 \\
17.3 \pm 1.3\end{array}$ & $\begin{array}{l}131 \pm 4 \\
193 \pm 20 \\
228 \pm 6 \\
323 \pm 27\end{array}$ & $\begin{array}{l}33.0 \\
52.1 \\
44.6 \\
52.1\end{array}$ & $\begin{array}{l}0.125 \\
0.195 \\
0.453 \\
0.603\end{array}$ & $\begin{array}{l}0.38 \\
0.37 \\
1.02 \\
1.16\end{array}$ \\
\hline
\end{tabular}

* Average deviation. 


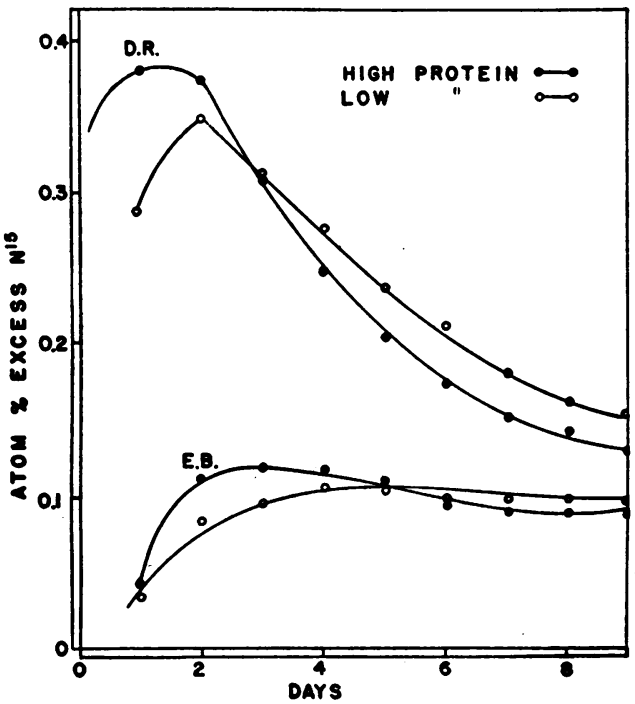

Fig. 1. The Abundance of $\mathrm{N}^{15}$ in Daily Urinary Uric Acid from a Normal and a Gouty Subject

The concentration of $\mathrm{N}^{15}$ as atom per cent excess has been plotted against time in days. Each subject was studied twice, first while on a low protein diet, then while on a high protein diet.

nitrogen into uric acid is more rapid when on a high protein diet is confirmed by the more rapid

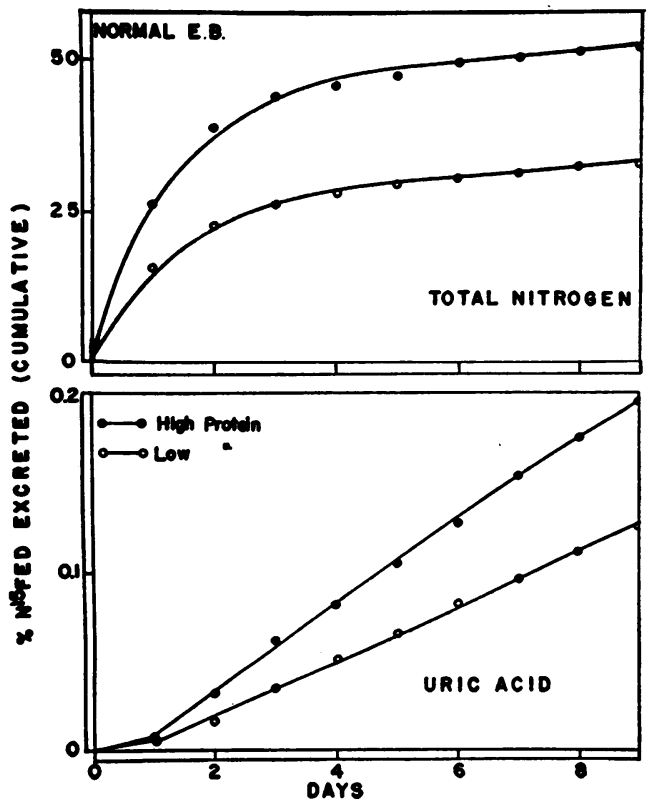

Fig. 2. The Excretion of $\mathrm{N}^{15}$ as Urinary Total Nitrogen and Uric Acid by a Normal Subject on a High and on a Low Protein Diet

The percentage of the total dose of administered $\mathrm{N}^{15}$ that was excreted has been plotted cumulatively. decline in isotope concentration in uric acid in the latter period of the experiment. At this time the glycine absorbed from the intestinal tract is, of course, predominantly glycine- $\mathrm{N}^{14}$.

These data, together with total $\mathrm{N}^{15}$ excretion data, have also been plotted as cumulative percentages of the $\mathrm{N}^{15}$ fed which was excreted as total urinary nitrogen and as uric acid (Figures 2 and 3 ). It will be noted that in both subjects an appreciably greater fraction of the administered glycine nitrogen was excreted in the total nitrogen

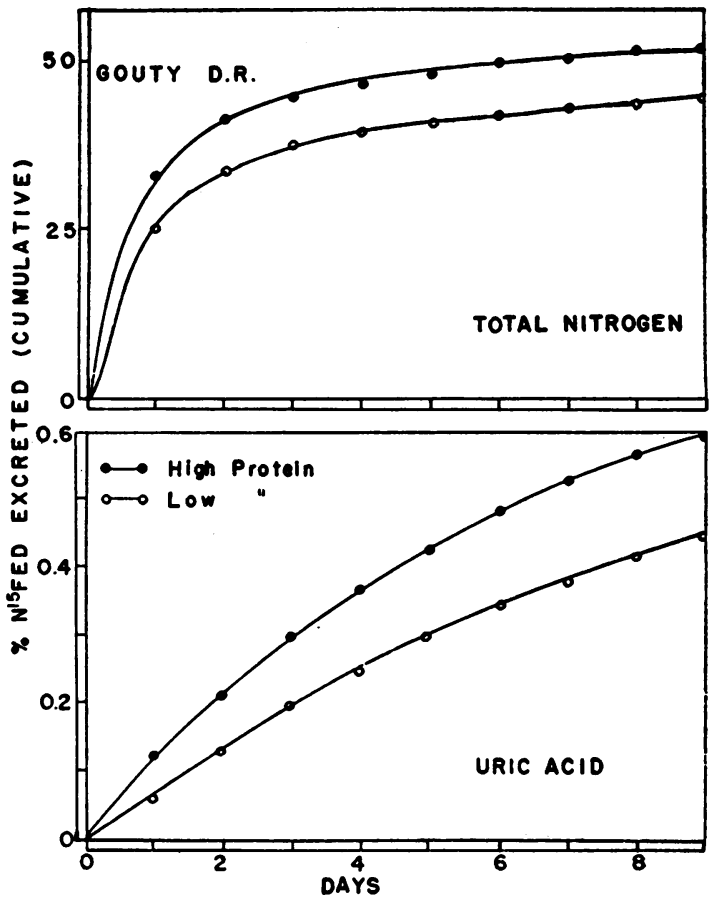

Fig. 3. The Excretion of $\mathrm{N}^{15}$ as Urinary Total Nitrogen and Uric Acid by a Gouty Subject on a High and on a Low Protein Diet

The percentage of the total dose of administered $\mathrm{N}^{15}$ that was excreted has been plotted cumulatively.

of the urine when a high protein diet was fed. This increase in total $\mathrm{N}^{15}$ excretion produced by dietary change is roughly paralleled by the increase in uric acid- $\mathrm{N}^{15}$ excretion. Indeed, in the normal subject (E. B., Table I) the per cent of excreted $\mathrm{N}^{15}$ which was found in uric acid appeared to be independent of the quantity of protein ingested. A change in protein intake which almost doubled the total urinary nitrogen excretion produced no significant alteration in this percentage $(0.38$ and 0.37$)$. In the gouty subject (D. R.) a 
considerably larger per cent of the excreted $\mathrm{N}^{15}$ was recovered in uric acid (1.02 and 1.16 on low and high protein diets). It is questionable whether the change of diet had any significant influence on the percentage in this instance.

When on a diet fortified with protein, both the normal and the gouty subject incorporated dietary glycine nitrogen, and presumably other dietary constituents, more rapidly into uric acid than when on a protein-poor diet. They also apparently delivered nitrogen from glycine to urea more rapidly when the diet was protein-rich and these two processes were accelerated in approximately parallel fashion.

It is hardly necessary to point out that these observations are too few to permit of any definitive conclusions. The present results would, however, appear to support the validity of restriction of dietary protein in situations, like tophaceous gout, where it would appear desirable to reduce to a minimum the rate of uric acid synthesis.

\section{SUMMARY}

Glycine- $\mathrm{N}^{15}$ has been fed in a standard experiment to one gouty and one normal subject, and the abundance of $\mathrm{N}^{15}$ in total urinary nitrogen and in urinary uric acid has been studied. Each subject was studied first while on a low protein diet and again while on a high protein diet.

Both in the normal and in the gouty subject, uric acid synthesis was found to be accelerated when the diet was fortified with protein. This acceleration was approximately paralleled by an acceleration in other metabolic pathways of glycine.

\section{REFERENCES}

1. Benedict, J. D., Roche, M., Yü, T. F., Bien, E. J., Gutman, A. B., and Stetten, D., Jr., Incorporation of glycine nitrogen into uric acid in normal and gouty man. Metabolism, 1952, 1, 3.

2. Benedict, J. D., Yü, T. F., Bien, E. J., Gutman, A. B., and Stetten, D., Jr., A further study of the utilization of dietary glycine nitrogen for uric acid synthesis in gout. J. Clin. Invest., 1953, 32, 775. 